\title{
Levels of complement C3 and C4 components in Amerindians living in an area with high prevalence of tuberculosis
}

\author{
Zaida Araujo/ ${ }^{+}$, Nieves González*, Laura de Cubeddu*, Rita C Ziegler*, \\ Jacobus H de Waard** , Francesca Giampietro, Domingo Garzaro***, Flor H Pujol***, \\ Neligia Carrasco de Serrano****, Amairany García de Saboin****
}

\author{
Cátedra de Inmunología, Escuela de Medicina “José María Vargas” *Laboratorio de Inmunohematología **Laboratorio de \\ Tuberculosis, Instituto de Biomedicina, Universidad Central de Venezuela, Apartado 4043, Caracas 1010, Venezuela \\ ****Laboratorio de Virología Molecular, Centro de Microbiología y Biología Molecular, Instituto Venezolano de Investigaciones \\ Científicas, Caracas, Venezuela ****Laboratorio Central, Hospital Vargas de Caracas, Caracas, Venezuela
}

The levels of complement C3 and C4 components were determined in non-indigenous (creoles) and indigenous (Warao) populations, the latter with an extremely high tuberculosis (TB) rate. Serum samples from 209 adults were studied and classified in 4 groups taking into account tuberculin skin tests (TST): (1) the group of Warao patients (58 positive for the TST, WP TST+ and 9 negative for the TST, WP TST-), (2) the group of creole patients (34 positive for the TST, CP TST+ and 9 negative for the TST, CP TST-), (3) the group of healthy Warao controls (38 positive and 14 negative for TST, WC TST+ and WC TST-, respectively), (4) the creole controls (26 positive and 21 negative for the TST, CC TST+ and CC TST-, respectively). With respect to the results concerning the measurement of both complement C3 and C4 components with the exception of the WC TST- and the CC groups, the WP TST+ and WP TST-as well as WC TST+ groups showed a significant-frequency of individuals with decreased levels of complement C3 component (20.6, 33.3, and 26.3\%, respectively) and also C4 component (12.0, 11.1, and 13.3\%, respectively) in comparison to both creole patients (CP TST+, 8.82\% and CP TST-, 0\% and CP TST+, 5.88\% and CP TST-, 0\%) for $C 3$ and $C 4$, respectively. The study of these parameters carried out in 15 Warao subjects with active infection, before and after anti-TB chemotherapy, statistically confirmed that the effective chemotherapy did not restore normal levels of the complement C3 and C4 components among Warao patients. Aditional tests for hepatitis $B$ or hepatitis $C$ infection, and the profile of the hepatic proteins were not associated to the deficiency in production of the complement components. In conclusion, the results show that within the Warao population, a high percentage of subjects exhibit decreased levels of both complement $C 3$ and C4 components independent of latent or active infection and the status of TST.

Key words: tuberculosis - body mass index - indigenous Warao - creole - complement C3 and C4 components

There were an estimated 8.4 million new tuberculosis cases in 1999, up from 8 million in 1997; the rise is due largely to a $20 \%$ increase in incidence in African countries most affected by the epidemic of HIV/AIDS. If present trends continue, 10.2 million new cases are expected in 2005, and Africa will have more cases than any other region of the world (WHO 2003). Evidence shows that complement plays a protective role in the host response to infection by different intracellular pathogens such as Mycobacterium tuberculosis. It has been reported that the outcome of the infection is associated with an enhancement of elements of the innate immune system, which include small peptides, such as defensins, that have the capacity to interact with and destroy organisms (Lehrer et al. 1993); receptor systems on phagocytes, such as Toll-like receptor and CD14, which facilitate the phagocytic and signaling processes by recognition of lipo-

Financial support: Fondo Nacional de Ciencia, Tecnología e Innovación, S1-2000000667

Correponding author: zaraujo@ telcel.net.ve

Received 26 October 2005

Accepted 15 May 2006 polyssaccharide and sugars on the surface of organims (Michael 2000). The complement proteins are of interest because they seem to be a key component of the innate immune system but have been recruited during the phylogenetic development of adaptive immunity to participate in this more sophisticated immune response as well (Michael 2000).

The complement cascade consists of 3 separate pathways that converge into a final common pathway. The pathways include the classic pathway (C1qrs, C2, C4), the alternative (C3, factor $\mathrm{B}$, properdin), and the mannanbinding (mannan-binding lectin, MBL). These 3 pathways converge at the component $\mathrm{C} 3$. The terminal complement pathway consists of all proteins activated after $\mathrm{C} 3$; the most notable of these is the C5-C9 group of proteins, known collectively as the membrane attack complex (MAC). The MAC exerts effective killing activity by creating perforations in cellular membranes (Bohlson et al. 2001). Deficiencies in complements predispose patients to infection via two mechanisms (Liszewski \& Atkinson 1998): ineffective opsonization and defects in lytic activity (defects in MAC). Specific complement deficiencies are also associated with an increased risk of developing autoimmune diseases such as systemic lupus erythematosus (SLE) (Michael 2000, Bohlson et al. 2001). 
The primary humoral immune response requires several days to occur and therefore in the early stages of host defence antibody-independent mechanisms of complement activation are extremely important (Bohlson et al. 2001). This is clear from the effects of deficiencies of complement components, particularly the alternative pathway components. Lack of these proteins increases susceptibility to infection because the biological effects of complements include promotion of chemotaxis and anaphylaxis, opsonization, and phagocytosis of microorganisms. In relation to this point, $\mathrm{C} 3$ is the most important central molecule in the complement system because both the classic and the alternative pathways activate it, and its activation products mediate opsonization and anaphylactic activity and also activate the terminal pathway.

Indigenous populations in Venezuela exhibit a high incidence of tuberculosis (Araujo et al. 2003). The Warao people of the Delta Amacuro state, have a very high prevalence of adult TB. In 1999 this state had a rate of 93.2 per 100,000 inhabitants. Of these $90 \%$ of the cases were present in Warao population (Araujo et al. 2003). In order to explore the complement functionality in this population with high TB exposure in adults, we report the evaluation of complement $\mathrm{C} 3$ and $\mathrm{C} 4$ components in the Warao indigenous from Venezuela.

\section{MATERIALS AND METHODS}

A total population of 209 adults between 15 and 60 years old livingin the visited indigenous communities of Delta Amacuro (rural area) and Caracas (urban area) was studied. Patients were diagnosed by the Regional Delta Amacuro Tuberculosis Program and the Tuberculosis Laboratory of the Institute of Biomedicine, based on respiratory symptoms characteristic of TB, the tuberculin skin test (TST), and smears and/or cultures. The population were classified in 8 groups according to TST: patient groups, Warao patients, 58 positive for the TST, (WP TST+) and 9 negative for the TST (WP TST-); creole patients, 34 positive for the TST (CP TST+) and 9 negative for the TST (CP TST-); control groups: Warao controls, 38 positive and 14 negative for TST the (WC TST+ and WC TST-, respectively), and creole controls, 26 positive and 21 negative for the TST (CC TST+ and CC TSTrespectively). Venous blood samples were obtained from volunteers, patients, and controls. The inclusion criteria were adopted from a report previously published by us (Fernández de Larrea et al. 2002, Araujo et al. 2003). Briefly, the study included Warao and creole people with or without respiratory symptoms, the former suggesting pulmonary TB based on clinical diagnosis, smears stained with Ziehl-Neelsen and/or microbiological cultures, individuals with $\mathrm{O}$ blood group $\mathrm{Rh}+$, with or without positive TST $(\geq 10 \mathrm{~mm})$ and patients with active TB who were HIV negative.

Confirmatory studies - For the confirmatory diagnosis, samples of sputum were obtained by expectoration in all highly suspected cases. Smears from sputum were stained by the Ziehl-Neelsen direct method. For each specimen (sputum) 2 tubes of modified Ogawa egg medium and Lowënstein-Jensen were inoculated using the swab method of Kudoh and Kudoh (1974) (for sputum as well as oozing). Anti-TB treatment was initiated on all confirmed cases, where bacteriological confirmation by bacilloscopy or culture was found, following the norms of Venezuelan National Tuberculosis Control Program (MSAS 1996). During and after anti-TB drug treatment, clinical and nutritional monitoring on all highly suspected patients was carried out in order to evaluate the improvement of these aspects as therapeutic confirmation, which allowed us to corroborate the diagnosis.

Complement $\mathrm{C} 3$ and $\mathrm{C} 4$ components - Measurement of the complement $\mathrm{C} 3$ and $\mathrm{C} 4$ components levels were measured by $\mathrm{C} 3$ and $\mathrm{C} 4$ commercial kits (a radial immunodiffusion test, Endoplate ${ }^{\mathrm{TM}}$, Single Radial Immunodiffusion Test Kits, Beckman Coulter ${ }^{\mathrm{TM}}$, US). The levels of C3 and $\mathrm{C} 4$ were determined in serum, which were isolated from venous blood obtained from controls and TB patients. The normal standardized values for each component were $101-186 \mathrm{mg} / \mathrm{dl}$ and $16-47 \mathrm{mg} / \mathrm{dl}$, respectively.

Other serological markers - HIV Diagnostic Test HIV testing was done with the Passive Particle Agglutination Test for the detection of antibodies to HIV-1 and/or HIV2 of FUJIREBIO Diagnostics (Abbott ${ }^{\circledR}$ LaboratorieDainabot Co. Ltd. Tokyo, Japan).

Hepatitis B surface antigen (HBsAg) was determined by a double sandwich monoclonal enzyme immunoassay, as previously decsribed (Pujol et al. 1993). Positivity in reactive samples was confirmed by testing with either HBsAg/MUREX (Abbott ${ }^{\circledR}$, IL, US) or HBsAg DIMA ${ }^{\circledR}$ (Caracas, Venezuela). Antibodies to hepatitis $\mathrm{C}$ virus (HCV) were determined by a synthetic peptide-based immunoassay (Aguilar et al. 2001). Positivity in reactive samples was confirmed by testing with a commercial antiHCV kit (anti-HCV DIMA ${ }^{\circledR}$, Caracas Venezuela).

In sera from Warao individuals, hepatic proteins were tested by different commercial kits: aspartate aminotransferase (AST) and alanino aminotransferase (ALT) by CHEMROY (Biochemical Trade, Texas), alkaline phosphatase (AP) and gamma glutamil transferase (GGT) by INVELAB, S.A. (Caracas, Venezuela), total proteins (TP), albumin (ALB), globulin (GLOB), ALB/GLOB and reactive $\mathrm{C}$ protein (RCP) by TECO DIAGNOSTIC (Anaheim, CA, US).

Statistical analysis - Statistical significance was performed by the Fisher's exact test and the Pearson test for correlations.

\section{RESULTS}

Distribution of average age and sex - The means and standard deviations from all adult patient and control groups are show in Table I. No difference was found between sex and average age.

Microbiological studies - Bacteriological studies of 67 and 43 sputum samples obtained by expectoration in Warao and creole patients showed that in 70 and $64 \%$ of patients, respectively, bacteria were confirmed, while 100\% sputum of both patient groups were positive by culture. Bacteria were not detected in any of the control Warao or creole individuals (Table I). 
TST - The TSTs were performed on all the individuals of this study using 2 tuberculin units of PPD of M. tuberculosis, strain RT-23, supplied by the Copenhagen World Health Organization reference laboratory (Denmark) and in current use by the Venezuelan Health Services. Testing and reading were done according to international guidelines (Snider 1982, Arnadottir et al. 1996). Intradermal injection of $0.1 \mathrm{ml}$ solution (tuberculin PPD) was administered by a trained nurse (from the Regional Delta Amacuro Tuberculosis Program) into the volar surface of the left forearm. The diameters of indurations were measured $72 \mathrm{~h}$ after inoculations; indurations of $\geq 10 \mathrm{~mm}$ were used as the criterion for infection with $M$. tuberculosis. Distribution of individuals with TST+ in the studied groups is shown in Table I. When the skin test reactivity was carried out in order to evaluate the state of specific cellular response, reactions of $\geq 10 \mathrm{~mm}$ were found in 86.5 and $79 \%$ of the Warao and creole patients, respectively, and in 73 and $55.3 \%$ of the Warao and creole controls (Table I).

Levels of complement C3 and C4 components - The percentages of individuals with decreased levels of complement $\mathrm{C} 3$ and $\mathrm{C} 4$ components are shown in Fig. 1A in comparison to those that exhibited enhanced levels of complement $\mathrm{C} 3$ and $\mathrm{C} 4$ components (Fig. 1B). In relation to the $\mathrm{C} 3$ levels, in the Warao patient group, a significant percentage of both WP TST+ and WP TST-presented decreased C3 (20.6 and 33.3\%, respectively) in comparison to both creole patients (8.82 and $0 \%$, respectively) (Fig. 1A). The decrease of $\mathrm{C} 3$ component correlated with a decrease of the $\mathrm{C} 4$ component, especially in the indigenous group. A significant percentage of both WP groups presented decreased levels of C4 (12 and 11.1\%, WPTST+ and WP-TST-, respectively) in comparison to both CP (5.8 and 0\%, CP-TST+ and CP-TST-, respectively) (Fig. 1A). In control groups, it was also found that a significant percentage of Warao people positive for the TST+, presented decreased C3 and also C4 (26.3 and 13.1\%, respectively) in comparison to both creole control positives and negatives for the TST $(0 \%$ for both the complement $\mathrm{C} 3$ and $\mathrm{C} 4$ components) (Fig. 1A).

The determination of those who presented increased levels of both complement $\mathrm{C} 3$ and $\mathrm{C} 4$ components showed
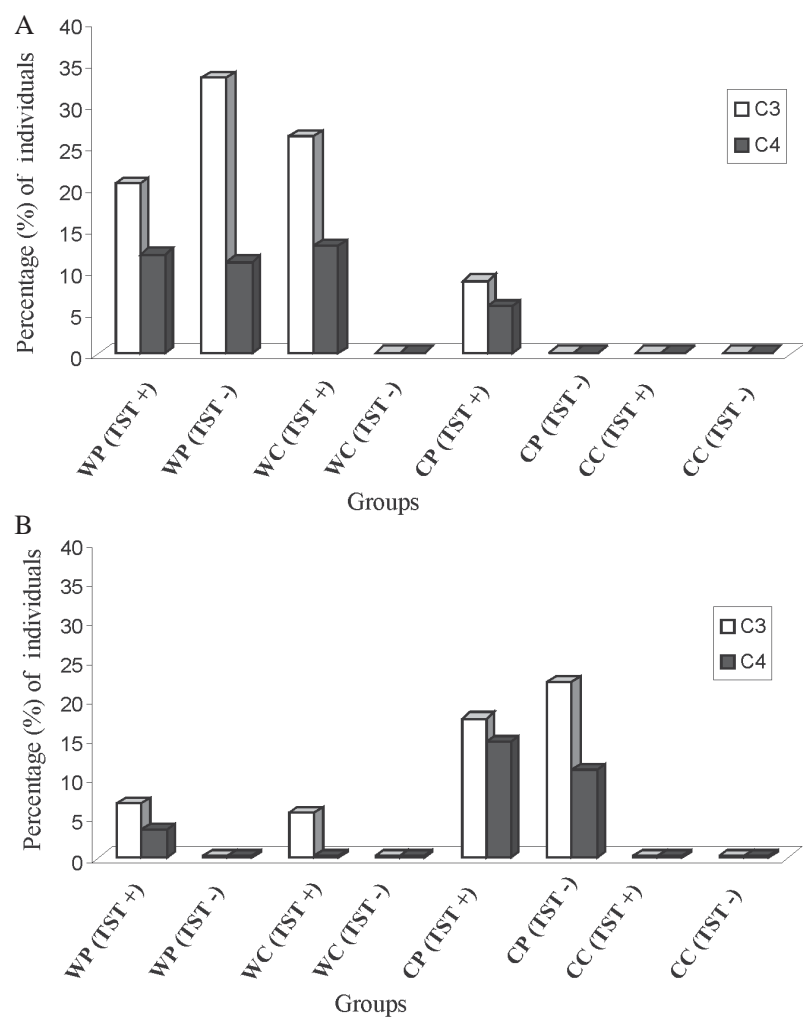

Fig. 1: data show the percentage of individuals according to positive or negative tuberculin skin test response (TST+ and TST-, respectively) with decreased (A) or increased (B) levels of complement $\mathrm{C} 3(\square)$ and $\mathrm{C} 4(\mathbf{\square})$ components among the different groups: Warao patients: (WP TST,$+ \mathrm{n}=58$ ) and (WP TST,$- \mathrm{n}=9$ ), creole patients: (CP TST,$+ \mathrm{n}=34)$ and (CP TST,$- \mathrm{n}=9)$, Warao controls (WC TST,$+ \mathrm{n}=38$ ) and (WC TST-, $\mathrm{n}=14)$, creole control $(\mathrm{CC}$ $\mathrm{TST}+, \mathrm{n}=26)$ and (CC TST,$- \mathrm{n}=21)$.

opposite results to those concerning the decreased levels of $\mathrm{C} 3$ and $\mathrm{C} 4$ components. Thus in the patient groups, both groups of creole patients, CP TST+ and CP TST-, presented a significan percentage of individuals with increased levels of C3 (17.6 and 22.2\%, respectively) in comparison to WP TST+ and WP TST-groups (6.8 and 0\%, respectively) (Fig. 1B). In relation to the levels of $\mathrm{C} 4 \mathrm{com}$ -

TABLE I

Immunological, bacteriological, and serological markers among Warao and creole patient and control groups

\begin{tabular}{lcccccr}
\hline Population/Marker & WP & WC & Total Warao & CP & CC & Total creole \\
\hline Age & $38.0 \pm 13.7$ & $32.2 \pm 11.9$ & $35.3 \pm 21.2$ & $32.2 \pm 11.9$ & $33.5 \pm 10.2$ & $31.4 \pm 13.9$ \\
TST+ $(\%)$ & $58 / 67(86.5)$ & $38 / 52(73.0)$ & $96 / 119(80.7)$ & $34 / 43(79.0)$ & $26 / 47(55.3)$ & $60 / 90(66.6)$ \\
Bacteria + $(\%)$ & $47 / 67(70)$ & $0 / 52(0)$ & $47 / 119(40)$ & $25 / 43(65)$ & $0 / 47(0)$ & $25 / 90(28)$ \\
Bacteria \pm culture $(\%)$ & $67 / 67(100)$ & $0 / 52(0)$ & $67 / 119(56)$ & $43 / 43(100)$ & $0 / 47(0)$ & $47 / 90(52)$ \\
Anti-HIV & 0 & 0 & 0 & 0 & 0 & 0 \\
HBsAg + $(\%)$ & $3 / 92(3.3)$ & $1 / 49(2)$ & $4 / 141(2.8)$ & 0 & 0 & 0 \\
Anti-HCV + $\%)$ & 0 & 0 & 0 & $1 / 47$ & $0 / 42$ & $1 / 89(1.1)$ \\
\hline
\end{tabular}

WP: Warao patients; WC: Warao controls; CP: creole patients; CC: creole controls; TST: tuberculin skin test. The levels of HBsAg were determined in serum by an ELISA and 2 commercial kits, (HBsAg/MUREX, Abbott ${ }^{\circledR}$, US and HBsAg DIMA ${ }^{\circledR}$, Venezuela). A sample with reactivity for 2 tests was considered positive. Antibodies to hepatitis $\mathrm{C}$ virus (HCV) were determined by a synthetic peptide-based immunoassay. Positivity in reactive samples was confirmed by testing with a commercial anti-HCV kit (anti-HCV DIMA $\left.^{\circledR}\right)$. 
ponents, a similar significantly high percentage of both creole patient groups, CP TST+ and CP TST-, with increased levels of C4 (14.7 and $11.1 \%$, respectively) was found, in comparison to WP TST+ and WP TST-groups (3.4 and $0 \%$, respectively) (Fig. 1B). In relation to control groups, while a lower percentage of WC TST+ showed increased levels of $\mathrm{C} 3(5.2 \%)$, neither group presented a percentage of individuals with increased levels of the $\mathrm{C} 3$ or C4 component (Fig. 1B). No difference was found between males and females in the levels of these components (data not shown).

The C3 and C4 components before and after treatment - There were statistically significant differences between the frequency of patients with decreased levels of $\mathrm{C} 3$ and $\mathrm{C} 4$ before $(2 / 15,13.3 \%$ and $0 / 15,0 \%$, respectively) and after $(6 / 15,40 \%$ and $3 / 15,20 \%$, respectively) treatment; p $<0.001$ (Fig. 2).

Chronic viral hepatitis markers - HBsAg was found in 4/141 Waraos and in none of the creole individuals. In contrast to what found for HBV, no anti-HCV antibodies were found among Waros and only one creole out of 89 was found positive (Table I). No association was found between chronic viral hepatitis and complement disfunction. In addition, hepathic proteins in serum were found within the normal values. There was no significant correlation between Warao individuals with decreased levels of components $\mathrm{C} 3$ and $\mathrm{C} 4$ and abnormal levels of hepathic proteins.

Profile of the hepatic proteins - The median values obtained for the hepatic proteins in sera from Warao individuals were found within the normal values. There was no significant correlation between Warao individuals with decreased levels of components $\mathrm{C} 3$ and $\mathrm{C} 4$ and abnormal levels of the hepathic proteins (Table II).

Profile of the hepatic proteins - The median values of the determination of the hepathic proteins in sera were found to be within the normal values (Table II). However, in relation to the results showing the percentage of individuals with increased or decreased levels of the hepathic proteins, it was observed that decreased levels of hepathic

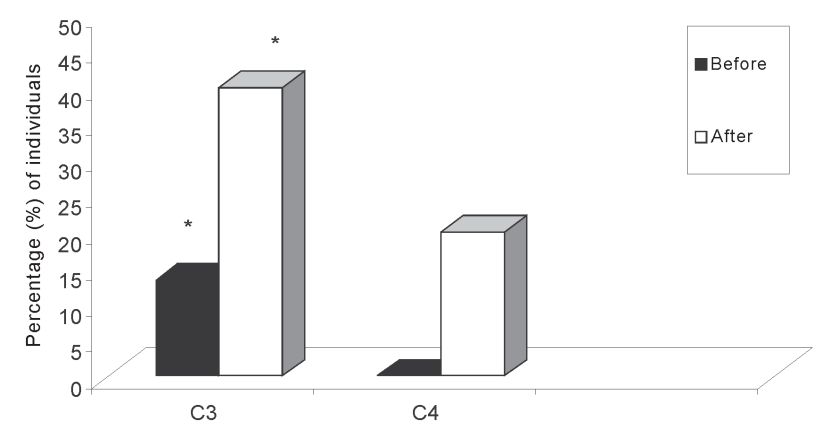

Fig. 2: percentage of patients with decreased levels of complement $\mathrm{C} 3$ and $\mathrm{C} 4$ components before $(\boldsymbol{\square})$ and after $(\square)$ anti-tuberculose treatment. The study included 15 Warao individuals independently of the tuberculin skin test status. Significant differences between decreased levels of complement $\mathrm{C} 3$ and $\mathrm{C} 4$ components before and after treatment were observed. proteins were more frequent in the patients than controls: AP (7.6\%), Gamma-GT (7.6\%), TP(15.3\%), ALB/GLOB $(15.3 \%)$, this last-named value also being decreased in the control group (20\%). In relation to the increased levels of these proteins, the levels of ALT/GPT were increased in the patient group (15.3\%), while those of RCP were increased both in patient and control groups (23 and 13.3\%, respectively). In order to study the levels of these proteins after anti-TB treatment, it was found that 20 and $40 \%$ of patients presented increased levels of TP and $\mathrm{RCP}$, respectively. There was no significant correlation between Warao individuals with decreased levels of components $\mathrm{C} 3$ and $\mathrm{C} 4$ and abnormal levels of the hepathic proteins (Table II).

TABLE II

Measurement of the hepatic proteins in Warao patient and control

\begin{tabular}{lcc}
\hline Group/marker & $\begin{array}{c}\text { Warao } \\
\text { patients } \\
(\mathrm{n}=13)\end{array}$ & $\begin{array}{c}\text { Warao } \\
\text { controls } \\
(\mathrm{n}=15)\end{array}$ \\
\hline AST/GOT $(0-40 \mathrm{U} / \mathrm{L})$ & $13.62 \pm 7.37$ & $7.67 \pm 3.75$ \\
ALT/GPT $(0-38 \mathrm{U} / \mathrm{L})$ & $16.15 \pm 15.97$ & $6.07 \pm 3.90$ \\
GAMMA-GT $(8-54 \mathrm{U} / \mathrm{L})$ & $16.23 \pm 8.22$ & $20.86 \pm 11.13$ \\
AP $(35-180 \mu / \mathrm{l})$ & $69.62 \pm 34.12$ & $62.21 \pm 15.62$ \\
ALB $(3.5-5.3 \mathrm{~g} / \mathrm{dl})$ & $3.93 \pm 0.78$ & $3.89 \pm 0.48$ \\
GLOB & $3.45 \pm 0.86$ & $3.46 \pm 0.59$ \\
ALB/GLOB & $1.81 \pm 0.47$ & $1.1 \pm 0.26$ \\
TP $(6.2-8.5 \mathrm{~g} / \mathrm{dl})$ & $7.26 \pm 1.1$ & $7.35 \pm 0.63$ \\
RCP $(\operatorname{Pos}>0.8 \mathrm{mg} / \mathrm{dl})$ & $1.41 \pm 3.55$ & $1.21 \pm 3.25$ \\
\hline
\end{tabular}

Median values of the determination of the hepathic proteins in sera from Warao individuals. AST/GOT: glutamic oxalacetic transaminase or aspartate aminotransferase; ALT/GPT: alanino aminotransferase; GAMMA-GT: gamma glutamil transferase; AP: alcaline phosfatase; ALB: albumin; GLOB: globulin; ALB/ GLOB: albumin/globulin; TP: total protein; RCP: reactive C protein.

\section{DISCUSSION}

The determination of the complement $\mathrm{C} 3$ and $\mathrm{C} 4$ components has shown that independently of the TST status and sex, a high percentage of Warao adult patients exhibited decreased levels of both $\mathrm{C} 3$ and $\mathrm{C} 4$ components. The decreased levels of these components were also found in almost the same percentage of Warao controls. In addition, the study of these parameters carried out in Warao with active infection, before and after anti-TB chemotherapy, confirmed that the effective chemotherapy did not restore normal levels of the complement $\mathrm{C} 3$ and $\mathrm{C} 4$ components among patients.

It has been reported that the biological effects of complements include promotion of chemotaxis and anaphylaxis, opsonization, and phagocytosis of microorganisms (Molina 2004). Since it is also known that $\mathrm{C} 3$ is the most important central molecule in the complement system because both the classic and alternative pathways activate it, and its activation products mediate opsonization and anaphylactic activity and also activate the terminal pathway, it seems probable that Warao individuals with $\mathrm{C} 3$ deficiency may develop severe episodes of 
recurrent meningitis or pneumonia; particularly acute respiratory tract infections are frequently observed in these communities as well as parasite infections (Doménico 1998, Araujo et al. 2003). However, it is probable that the majority of Warao people do not have absolute deficiencies of these components as such. The MBL pathway, might be compensating these deficiencies. The production of the opsonins would then be present, which would probably confer protection against infections (Michael 2000).

On the other hand, other factors could be involved in relation to these deficiencies such as genetic aspects and type of alimentation. It has also been reported that patients with severe malnutrition have low complement levels (Michael 2000). BMI, used as an indicator of nutritional status (Liszwski \& Atkinson 1998, dos Anjos et al. 1998), has been found to decrease with age in Warao population, probably because of high levels of malnutrition (Holmes 1997, Araujo et al. 2003). It has been reported that the different nutritional profile in a population results from the specific patterns of social, cultural, and economic conditions of each population (Liszewski 1998); the type of feeding in Warao communities is in concordance with their cultural patterns - basically, they eat fish and plant "conucos" (strips of land) along the river banks with taro, their principal source of calories (Holmes 1997, Doménico 1998, Fernández de Larrea et al. 2002). However, inherited conditions cannot be excluded. In 1988, the Warao were tested in relation to this subject; the data illustrated HLA haplotypes, linkage-disequilibrium, and DR/DQ associations not seen previously in other human populations (Layrisse et al. 1988). However, no associations have been established between these findings and complement deficiencies in this population. In addition, while no definitive racial patterns of association have been established for the majority of complement deficiencies, ethnic predispositions have been described for some complement deficiencies. For example, deficiencies in properdin and $\mathrm{C} 2$ have been associated with the white race, C6 deficiencies have been shown to have a possible predisposition in African populations, and deficiencies in C8 have been associated with an Asian racial background. However, for most of these deficiencies, the absolute number of patients studied has been quite small. Moreover, it has been reported that complement deficiencies are relatively rare worldwide (Michael 2000), so it is not viable to make estimates of prevalence of the $\mathrm{C} 3$ and $\mathrm{C} 4$ deficiencies based on results from this study in Warao adult communities. In a study testing these components in Warao children where there is also a high prevalence of TB and particularly acute respiratory tract infections (Holmes 1997), contradictory results were obtained in the childhood population studied. While there was a significant percentage of patient and control children with enhanced levels of C3 (42.1 and $30.7 \%$, respectively), and $\mathrm{C} 4$ (10.3 and $12.5 \%$, respectively), a lower percentage of child patients presented decreased levels of $\mathrm{C} 3(3.4 \%)$ and $\mathrm{C} 4(4.1 \%)$, and none of the healthy controls had decreased levels of components. In addition, the deficiency observed of both $\mathrm{C} 3$ and $\mathrm{C} 4$ in the Warao were not associated with chronic viral hepatitis or with abnormal hepatic proteins levels.
It has been reported that individuals with complement deficiencies tend to present recurrent infection. Most gram-negative bacteria can activate complements by both pathways. Most of these bacteria are resistant to the membrane attack complex (MAC) but susceptible to phagocytosis (Molina 2004). On the other hand, gram-positive bacteria activate complements by the alternative pathway, which leads to the generation of both $\mathrm{C} 3 \mathrm{~B}$ and $\mathrm{iC} 3 \mathrm{~b}$ bound covalently to the bacterial surface. $\mathrm{C} 3 \mathrm{~b}$ is the predominant form bound to intact bacteria (Michael 2000, Molina 2004). It has been reported that unlike other bacteria, Mycobacterium can activate both the alternative and classical complement pathways in the absence of specific antibodies (Bohlson et al. 2001). However, in studies that investigated the importance of the host complement system in the pathogenesis of disease mediated by the pathogen $M$. avium, the results showed that $\mathrm{C} 3$-sufficient mice and C3-deficient mice were equally susceptible to infection by M. avium (Bohlson et al. 2001). Taking into account these findings and since the complement proteins play an important role in innate immunity, promoting inflammation and microbial killing, it is likely that, in Warao people where a high prevalence of TB occurs, independently of the TST response, the decreased levels of these components could be correlated with recurrent high prevalence to acute infections, unusual opportunistic infecting agents, and also overwhelming parasite infections that could contribute to the establishment of chronic infections such as TB from an early age. Further studies are needed to understand the reduction in $\mathrm{C} 3$ and $\mathrm{C} 4$ levels, which seem to decrease with age among Warao indigenous.

\section{ACKNOWLEDGEMENTS}

To Mark Gregson for critical review of the manuscript. To Iraida Debora for technical assistance.

\section{REFERENCES}

Aguilar MS, Cosson C, Loureiro CL, Devesa M, Martínez J, Villegas L, Flores J, Ludert JE, Alarcón De Noya B, Noya O, Liprandi F, Pujol FH 2001. Prevalence of hepatitis C virus infection in Venezuela assessed by a synthetic peptide-based immunoassay. Ann Trop Med Parasitol 95: 187-195.

Anjos LA 1992. Body mass index (body mass.body height-2) as indicator of nutritional status in adults: review of the literature. Rev Panam Saude Pública 26: 431-436.

Araujo Z, Fernández de Larrea C, López D, Fandiño C, Chirinos M, Convit J 2003. Hematologic values among indians with tuberculosis from the Orinoco delta of Venezuela. Acta Cient Venez 54: 247-253.

Arends T 1992. Estructura Genética de la Población Indígena de Venezuela, La Universidad de las Naciones Unidas, Caracas, p. 85-92.

Arnadottir T, Rieder HI, Trébuq A, Waaler H 1996. Guidelines for conducting tuberculin skin test surveys in high prevalence countries. Tuber Lung Dis 77: 1-20.

Bohlson SS, Strasser JA, Bower JJ, Schorey JS 2001. Role of complement in Mycobacterium avium pathogenesis: in vivo and in vitro analyses of the host response to infection in the absence of complement component C3. Infect immune 69: 
$7729-7735$

Censo Indígena de Venezuela 1992. Nomenclador de asentamientos, Tomo II, Oficina Central de Estadística e Informática, Caracas, Febrero 1995.

Crofton J, Horne N, Miller F 1992. Clinical Tuberculosis, McMillan Education, Chile, p. 124-130.

Doménico C 1998. Informe Warao CVP-Fundación Zumaque. Primicia. Febrero 14: 32-38.

dos Anjos LA, da Veiga GV, de Castro IR 1998. Distribution of body mass indices of a Brazilian population under 25 years of age. Rev Panam Salud Pública 3: 164-173.

Fernández de Larrea C, Fandiño C, López D, del Nogal B, Rodríguez N, Convit J, Araujo Z, de Waard JH 2002. Childhood tuberculosis in the Warao population in Venezuela. Invest Clin 43: 35-48.

Holmes R 1997. Evaluation of the socio-sanitary conditions in five Warao communities of the Delta centro block in preparation for the elaboration of a 5 to 10 year social investment plan, Holmes Consultores, p. 1-29.

Kudoh S, Kudoh T 1974. A simple technique for culturing tubercle bacilli. Bull WHO 51:71-82.

Layrisse Z, Heinen HD, Balbas O, García E, Stoikow Z 1988. Unique HLA-DR/DQ associations revealed by family studies in Warao Amerindians. Haplotype and homozygosity frequencies. Hum Immunol 23: 45-57.

Lehrer RI, Lichtenstein AK, Ganz T 1993. Defensins: antimicrobial and cytotoxic peptides of mammalian cells. Ann Rev Immunol 11: 105-128.

Lim TO, Ding LM, Zaki M, Suleiman AB, Fatimah S, Siti S, Tahir A, Maimunah AH 2000. Distribution of body weight, height and body mass index in a national sample of Malaysian adults. Med J Malaysia 55: 108-128.

Liszewski MK, Atkinson JP 1998. Regulatory proteins of complement. In MM Frank, JE Volanakis (eds), The human Complement System in Health and Disease, Marcel Dekker, New York, p. 149-166.

López Blanco M, Landaeta M 1991. Manual de Crecimiento y Desarrollo, Fundacredesa, Caracas.

Michael M Frank 2000. Primary immune deficiencies: presentation, diagnosis, and management. Pediatric Clinics of North America 47: 1-7.

Molina H 2004. Complement and immunity. Rheum Dis Clin N Am 30: 1-18.

MSAS 1996-Normas para el primer nivel de atención. Actualización. Programa Nacional Integrado de Control de la Tuberculosis. División de Tuberculosis y Enfermedades Pulmonares, Caracas, Venezuela.

Pujol FH, Rodríguez I, Devesa M, Rangel-Aldao R, Liprandi F 1993. A double sandwich monoclonal enzyme immunoassay for detection of hepatitis B surface antigen. J Immunoassay 14: 21-31.

Seminario Técnico-Administrativo 1999. Programa Integrado de Control de la Tuberculosis. Ministerio de Sanidad y Asistencia Social, Caracas.

Snider DE 1982. The tuberculin skin test. Am Rev Respir Dis 125: 102-104.

WHO-World Health Organization 1986. Use and Interpretation of anthropometric indicators of nutritional status. Bull WHO 64: 929-941.

WHO-World Health Organization 2003. Global Tuberculosis Control Report, Geneva. 